\title{
Buddhist philosophical teachings for environmental
}

\section{conservation}

\author{
Dilakshi R.De Silva \\ Senior Lecturer,Department of Philosophy \\ Faculty of Social Sciences, University of Kelaniya SriLanka. \\ dilakshi84@gmail.com
}

\begin{abstract}
$\underline{\text { Abstract }}$
Mankind and the environment are interconnected. Moreover, the major factor of the mankind survival is interdepend on the environment. However, with the erosion and growth of mankind's activity, many environmental problems have been created. As major issues water pollution, air pollution, noise pollution can be identified. The significance of this is that the techniques used for their own preservation are based on a technical mentality. Thus, the pre-philosophical era has been described how environment should be preserved through the religious contexts. Initially, philosophical teachings on Buddhist conservation are of an eternal value in the Buddhist philosophy. Knowing the importance of the environment and its impact on human life is an incentive for the environment. Consider about, the Buddhism it has paid special attention, regarding the environment and environmental preservation. The main objective of this research is to study Buddhist philosophical teachings on environmental issues and how to conserve the environment. The research is, focuses on the following three perspectives.
\end{abstract}

1. Buddhist view of environmental usage

2. Environmental conservation measures established by the Buddhist Disciplinary Statutes

3. Environmental conservation methods introduced in Buddhist Suttra 


\section{$2^{\text {nd }}$ International Conference on}

\section{SOCIAL SCIENCE, HUMANITIES \& EDUCATION \\ 21 - 23 JUNE 2019 \\ VIENNA, AUSTRIA}

The research method, is of this study primarily depended on historical sources which found by secondary source of data. Buddhism pointed out that in this timeless teaching, solutions have been made to the entire environmental issues via self-conservation. Accordingly, the Buddhist philosophy has pointed out that there are different conservation methods consisted with strategy and ethics to be used in the environment conservation. In order, to have a friendly and sensitive attitude towards the physical environment, a person must have a strong characteristic development. As a key element of environmental conservation, it is pointed out that the environment should be preserved through the self-discipline of person by using disciplinary orders. Those high qualities can inspired the mankind to use the environment properly. The prospect of Buddhist teaching is that produce a man, such like contentment (santussako) Easy to feed (subharo) not busy (appakichcho) Lightweight (sallahika uththi) tranquil senses (santhindriyo) and well knowledge (nipako).

Key Words: Buddhist Philosophical Teachings, Buddhism,Environmental Conservation, Mankind, Pollution. 